\title{
A INCONSTITUCIONALIDADE DO PROJETO DE LEI N. 4.148/2008 DIANTE DO DIRETO DE INFORMAÇÃO
}

\section{THE UNCONSTITUTIONALITY OF THE BILL N. 4.148/2008 BEFORE THE RIGHT TO INFORMATION}

\author{
${ }^{1}$ Gustavo Paschoal Teixeira de Castro Oliveira \\ ${ }^{2}$ Sinvaldo Conceição Neves
}

\section{RESUMO}

Este artigo trata de questões correlatas à necessidade de se assegurar o direito à informação sobre o consumo de alimentos à base de organismos transgênicos, estribando-se na diretriz de vedação ao retrocesso quanto à supressão de norma que regulamenta direito fundamental. Trata-se de um estudo exploratório, de abordagem qualitativa, analisando a situação através de lógica dedutiva, fundamentada nas seguintes fontes: Constituição Federal, legislação infraconstitucional, Projeto de Lei, julgado, e doutrina, com o fito de se entender qual o devido procedimento a ser seguido pelo sistema de produção e consumo, no que tange ao direito à informação ao consumidor, amparado constitucionalmente.

Palavras-chave: Organismos transgênicos, Direito à informação, Consumidor, Direito fundamental

\begin{abstract}
This article deals with questions related to the necessity to make sure the right of transgenic food consumption information according to the principle of regression prohibition. It is an explorative study with qualitative approach that seeks analyze the situation through deductive logic based on the following laws: Federal Constitution, ordinary legislation, law project 4.148/08, law 8.078/92, decisions of Superior Tribunal de Justiça and renowned authors intending to understand the right procedure to be followed by the system of production and consumption related to the right of information, constitutionally protected.
\end{abstract}

Keywords: Transgenic organisms, Information right, Costumer, Fundamental right

1 Doutor em Direito das Relaç̃es Internacionais pelo Centro Universitário de Brasília. Advogado. Centro Universitário de Brasília - UniCEUB, Brasília, Distrito Federal. Brasil - E-mail: gustavopaschoal1@gmail.com 2 Mestrando em Direito pelo Centro Universitário de Brasília. Centro Universitário de Brasília - UniCEUB, Brasília, Distrito Federal. Brasil - E-mail: sinvaldo@ceulp.edu.br 


\section{INTRODUÇÃO}

$\mathrm{O}$ aumento significativo da população mundial obrigou o setor produtivo a adotar novas tecnologias capazes de propiciar um importante incremento da produtividade. Está, entre essas novas tecnologias, o emprego de métodos de engenharia genética, capaz de modificar a essência de víveres tradicionalmente cultivados pelo homem. Entretanto, com o uso de novas técnicas, foi possível cruzar duas espécies de vegetais ou até um vegetal com um animal, tornando o produto final mais resistente a pragas e fatores genéticos.

Acompanhando as benesses experimentadas pela implementação da produtividade, a sociedade também passou a experimentar o risco, aqui entendido como as incertezas surgidas com a exposição a essa nova realidade. Dentro desse cenário, o ordenamento jurídico lançou mão da figura da informação, como mecanismo capaz de equilibrar as relações decorrentes das novas tecnologias. Ora, uma vez que o consumidor, destinatário final do processo produtivo, será o usuário desses novos produtos, nada mais razoável do que esclarecê-lo dos potenciais riscos aos quais está sendo submetido.

A informação passou a ter uma importância tão grande como mecanismo de desenvolvimento, que o legislador constituinte achou por bem alçar a informação a status de norma constitucional.

$\mathrm{Na}$ perspectiva da concretização de direitos fundamentais, as normas infraconstitucionais, em especial as voltadas para a defesa do consumidor, passaram a explorar o instituto da informação, permitindo sua aplicação nas mais variadas facetas da relação de consumo. Andando na contramão desse movimento, tramita no âmbito do Congresso Nacional o projeto de Lei n. 4.148/2008, o qual desobriga os fornecedores de utilizar na rotulagem a informação de que aquele produto é composto por matéria prima geneticamente modificada.

Foram elaboradas, de um lado, várias normas de proteção à figura do destinatário final. De outro, uma corrente carreada sobretudo pela classe ruralista, almeja a flexibilização das relações de consumo, traduzida pelo Projeto de Lei n. 4.148/2008. A artigo em questão buscará abordar aspectos jurídicos tidos como (in)compatíveis ao referido projeto de lei, sobretudo no tocante ao direito à informação e à proteção do consumidor.

Para a devida sistematização do estudo, mister se faz análise conjunta de legislação pertinente ao referido projeto de lei (Constituição Federal, Lei n. 11.105/2005, Decreto n. 
4.680/2003, e Lei n. 8.078/90 - Código de Defesa do Consumidor, CDC), bem como doutrina e julgado, no intuito de se evidenciar a necessidade da devida preocupação e cautela de possíveis riscos ante interesses difusos. Buscar-se-á discorrer e analisar questões correlatas à sociedade de risco e processo de produção, bem como seu vínculo com o(a)s consumidore(a)s e os devidos direitos fundamentais, com ênfase ao direito à informação. Tentar-se-á compreender, ao final, as seguintes problemáticas: de que maneira questões consumeristas podem ser colocadas em xeque ante à possível aprovação do Projeto de Lei n. 4.148/2008? Trata-se de avanço ou retrocesso quanto aos direitos fundamentais da informação e consumo?

\section{A MASSIFICAÇÃO DA PRODUÇÃO E O SURGIMENTO DO DIREITO DO CONSUMIDOR}

Durante muitos séculos, o processo de produção de produtos e de prestação de serviço era feito de modo artesanal, assim, o produto era fabricado quase que personalizado, tendo o consumidor condições de contratar em condições de igualdade com o fabricante. Entretanto, por volta do século XVIII, o mundo assistiu a uma profunda transformação na forma como se produziam os produtos ofertados no mercado de consumo. Os fabricantes passaram a adotar novas tecnologias, as quais impulsionaram o processo de fabricação permitindo que aquilo que antes era feito de modo artesanal passasse a ser produzido em série.

Diante desse novo meio de produzir, viu-se surgir um desequilíbrio de forças entre a figura do fornecedor e do consumidor, que passou a ser visto como vulnerável. O Direito do Consumidor surgiu, assim, como ramo autônomo, a partir da constatação de que as regras do direito privado não eram suficientes para proteger efetivamente seus interesses. Nunes (2005, p.55) leciona que

[...] as bases jurídicas existentes no século mencionado estão ligadas ao liberalismo econômico e às grandes codificações, que se iniciam com o Código de Napoleão de 1804. Os pressupostos do pensamento liberal aparecem no sistema jurídico codificado, como, por exemplo, foi estabelecido no Código Civil de 1916 (e que entrou em vigor em 1917). Destaque-se, dentre os vários pontos de influência do liberalismo, a chamada autonomia da vontade, a liberdade de contratar e fixar cláusulas, o pacta sunt servada etc. Nessa mesma época, ou seja, no começo do século XX, instaurase definitivamente um modelo de produção, que terá seu auge nos dias atuais. Tal modelo é a massificação: fabricação de produtos e oferta de serviços em série, de forma padronizada e uniforme, no intuito de diminuição do custo de produção, atingimento de maiores parcelas de população como o aumento da oferta etc. Esse sistema de produção pressupõe a homogeneização dos produtos e serviços e a estandardização das relações jurídicas que são necessárias para a transação desses bens. A partir da Segunda Guerra Mundial o projeto de produção capitalista passou 


\begin{abstract}
a crescer numa enorme velocidade, e, com o advento da tecnologia de ponta, dos sistemas de automação, da robótica, da telefônica por satélite, das transações eletrônicas, da computação, da microcomputação etc., a velocidade tomou um grau jamais imaginado até meados do século XX. A partir de

1989, com a queda dos regimes não capitalistas, o modelo de globalização, que já se havia iniciado, praticamente completou seu ciclo, atingindo quase todo o globo terrestre. $\mathrm{O}$ direito não podia ficar à margem desse processo, e em alguma medida surgiu à tendência de produção em série, mormente de especialização (outra característica desta nossa sociedade). Mas, de início, a alteração observada foi a do lado do fornecedor, que passou a criar contratos-padrão e formulários (que depois vieram a ganhar o nome de contratos de adesão) de forma unilateral e a impingi-los aos consumidores.
\end{abstract}

Percebe-se, portanto, que questões jurídicas pertinentes a consumo, tais como percepção, valoração e normatização encontram-se conectadas com avanço tecnológico e acontecimentos históricos No Brasil, o processo de consolidação do Direito do Consumidor como ramo de direito autônomo se deu com a promulgação da Constituição Federal de 1988. Ressalta-se que o legislador constituinte, buscando robustecer a defesa do consumidor no cenário jurídico brasileiro, deu e este status de direito fundamental. Ademais, ainda na esfera constitucional, o direito do consumidor é tratado como princípio da ordem econômica, bem como no Ato das Disposições Constitucionais Transitórias, que inclusive prevê expressamente uma norma infraconstitucional de proteção dos consumidores.

Atendendo a premissa constitucional, foi editada a Lei n. 8.078, de 11 de setembro de 1990, dispondo sobre normas de proteção e defesa do consumidor, de ordem pública e interesse social, nos termos dos arts. $5^{\circ}$, inciso XXXII, 170, inciso V, da Constituição Federal, e art. 48 de suas Disposições Transitórias.

Na visão de Bittar (2002), as desigualdades decorrentes da relação de consumo não encontram no sistema de consumo embasado no liberalismo mecanismo eficientes para se reequilibrar a relação jurídica. A análise do surgimento do CDC feita pelo Prof. Tartuce (2012) sustenta que o contexto da autonomia da Direito do Consumidor o tipifica como uma norma pós-moderna, podendo ser identificado pela ideia de unidade mundial chamada de globalização.

A elaboração do presente Código foi resultado de um longo processo histórico, que levou em consideração a vulnerabilidade do consumidor no mercado de consumo. Na lição de Marques (2007), o direito do consumidor é uma disciplina transversal entre as áreas de direito público e privado, cuja finalidade visa a proteger um sujeito de direitos, o consumidor, em todas as relações jurídicas frente ao fornecedor. 
O reconhecimento do consumidor como sujeito de direito é algo que ocorreu há pouco tempo, entretanto, antes desse momento histórico, o consumidor era tratado como "contratante" ou "cliente", o que denota uma visão individual de seus direitos, sendo raro o conhecimento coletivo (MARQUES, 2007, p. 23).

É imperioso reconhecer as grandes inovações normativas trazidas pelo CDC, sobretudo no tocante à tutela coletiva do consumidor. Na visão de Neves e Tartuce (2012, p. 9), o CDC é composto por normas que têm relação direta com a terceira geração, era ou dimensão, relativas aos direitos da fraternidade.

É salutar acrescentar que, juntamente com outras normas, o CDC tem significativo um significativo avanço na efetivação da tutela dos direitos coletivos no direito brasileiro, tanto assim que alguns afirmam se tratar de um código de direitos coletivos.

Ademais, com o objetivo de proteger uma parcela da sociedade reconhecidamente vulnerável e segregada de direitos, o legislador sistematizou a lei consumerista na forma de um microssistema jurídico, que se caracteriza pela pluralidade de normas. Dessa forma, é possível reconhecer na seara do CDC normas de direito de direito material ou processual ${ }^{1}$.

No que pese a primeira impressão de o CDC ser um microssistema jurídico isolado, tal raciocínio não mercê prosperar, pois a sistemática de proteção da norma viabiliza que outras normas sejam agregadas ao arcabouço jurídico.

\section{O RISCO COMO NOVO PARADIGMA DO PROCESSO PRODUTIVO}

Com a incorporação de novas tecnologias e métodos no processo de produção de produtos a serem ofertados no mercado de consumo, foi possível agregar novas facilidades e comodidades para a sociedade. Na visão de Beck (2010), os riscos são tão antigos quanto o próprio desenvolvimento industrial. Antes mesmo do processo de massificação decorrente da revolução industrial, a sociedade já convivia com os riscos surgidos em razão da grande pobreza que assolava boa parte da população.

1 Processo: REsp 1009591 RS 2007/0278724-8. Relator(a): Ministra NANCY ANDRIGHI. Julgamento:

13/04/2010. Órgão Julgador: T3 - TERCEIRA TURMA. Publicação: DJe 23/08/2010. CONSUMIDOR E CIVIL. ART. $7^{\circ}$ DO CDC. APLICAÇÃO DA LEI MAIS FAVORÁVEL. DIÁLOGO DE FONTES. RELATIVIZAÇÃO DO PRINCÍPIO DA ESPECIALIDADE. RESPONSABILIDADE CIVIL. TABAGISMO. RELAÇÃO DE CONSUMO. AÇÃO INDENIZATÓRIA. PRESCRIÇÃO. PRAZO. O mandamento constitucional de proteção do consumidor deve ser cumprido por todo o sistema jurídico, em diálogo de fontes, e não somente por intermédio do CDC. Assim, e nos termos do art. $7^{\circ}$ do $\mathrm{CDC}$, sempre que uma lei garantir algum direito para o consumidor, ela poderá se somar ao microssistema do CDC, incorporando-se na tutela especial e tendo a mesma preferência no trato da relação de consumo. Diante disso, conclui-se pela inaplicabilidade do prazo prescricional do art. 27do CDC à hipótese dos autos, devendo incidir a prescrição vintenária do art. 177 do CC/16, por ser mais favorável ao consumidor. Recente decisão da $2^{a}$ Seção, porém, pacificou o entendimento quanto à incidência na espécie do prazo prescricional de 05 anos previsto no art. 27 do CDC, que deve prevalecer, com a ressalva do entendimento pessoal da Relatora. Recursos especiais providos. SUPERIOR TRIBUNAL DE JUSTIÇA. REsp 10095091. Decisões monocráticas. Disponível em: < http://www.stj.jus.br/SCON/decisoes/toc.jsp?livre=REsp+1009591+RS+2007\%2F0278724-

$8 \& \& b=D T X T \&$ thesaurus=JURIDICO $>$. Acesso em 12 jan. 2016. 
Apesar de o risco ser inerente à vida em grupo, somente com o implemento da produção possibilitado pela uso de um novo modelo é que o risco passou a ser socializado. Apesar das facilidades propiciadas ao ser humano pelas novas técnicas, foi necessário que a sociedade reconhecesse e assumisse os riscos decorrentes desse processo tecnológico.

As incertezas da vida moderna não surgem apenas de eventos cataclísmicos naturais, mas, sobretudo, dos riscos inerentes às novas tecnologias criadas pelo próprio homem, como internet, transgênico, materiais nucleares, entre outras (LOPEZ, 2010).

São inúmeras as situações de riscos decorrentes das inovações humanas que assustaram ou assustam a sociedade. Podem-se citar os casos envolvendo a internet, que tem o condão de expor tudo e a todos ao escrutínio público, como preservar a intimidade e a privacidade diante dessa ferramenta? (LOPEZ, 2010).

A globalização se mostrou um impressionante fenômeno econômico social que permitiu a integração de capitais, pessoas e instituições de diferentes regiões do planeta. Entretanto, apesar das inúmeras possibilidades benéficas, a globalização permitiu significativo aumento do ódio, combustível das atividades terroristas espalhadas por todo o globo.

Nessa perspectiva, surge o princípio da precaução, originada na Declaração do Rio 92, o qual preconiza que, quando existir ameaças de danos irreparáveis ou de difícil reparação ao meio ambiente, devem-se tomar todas as cautelas para se evitar ou minimizar esse impacto. Ademais, a ausência de certeza científica não pode ser utilizada como justificativa para se adotarem medidas de proteção ao meio ambiente (SIRVINSKAS, 2003).

O princípio da precaução, diante de riscos advindos do processo tecnológico, encontra um ambiente propício para se robustecer, pois os novos riscos são desconhecidos, incalculáveis e incontroláveis (AFONSO, 2008).

Diante de uma nova realidade social surgida a partir do emprego e da popularização da tecnologia, as regras advindas de um direito voltado para a solução individual não se mostraram eficientes. Foi necessário repensar o modelo jurídico abandonando, ou ao menos mitigando, o modelo voltado ao direito individual e adotar um direito voltado para as sociedades de massa.

Nesse cenário, as normas voltadas para o consumidor se propõem a assegurar a efetivação de sua proteção e a defesa, utilizando-se de instrumentos de direito coletivo, afinal, já que é o processo produtivo que advêm os riscos aos quais se submetem os consumidores, nada mais salutar do que uma norma com viés voltado para os direitos difusos. 


\section{A INFORMAÇÃO NA EFETIVAÇÃO DE DIREITOS FUNDAMENTAIS}

Dentro da sistemática da proteção e defesa do consumidor, a informação tem se revelado uma importante arma capaz de equilibrar a, naturalmente, desequilibrada relação de consumo.

A informação nas relações sociais decorre de princípio geral do direito da boa-fé, que antes de ser positivado já impunha a obrigatoriedade das relações jurídicas serem pautadas pela honestidade recíproca.

Hodiernamente, a boa-fé objetiva pode ser vista positivada em leis, como no Código de Proteção e Defesa do Consumidor e no Código Civil, e dela decorrem deveres como confiança, probidade, lealdade e informação.

O Código Civil de 2002 também trouxe de forma expressa o princípio da boa-fé objetiva. Apesar de estarem em diplomas legislativos separados, deve-se fazer uma análise sistemática entre as diferentes leis, razão pela qual a I Jornada de Direito Civil realizada pelo Conselho da Justiça Federal editou o enunciado n. 27: “Art. 422. Na interpretação da cláusula geral da boa-fé, deve-se levar em conta o sistema do Código Civil e as conexões sistemáticas com outros estatutos normativos e fatores metajurídicos".

Neves e Tartuce (2012) analisam a boa-fé objetiva considerando o aspecto histórico, mencionando que houve uma evolução que parte do plano psicológico ou intencional (boa-fé subjetiva) e passa para o plano da conduta humana.

Salienta-se que, com o advento da Constituição Federal, o direito de informação passou a ter status de direito fundamental, devido a sua previsão no art. $5^{\circ}$, inciso XXXIII, do texto constitucional, em que é assegurado que todos têm o direito de receber informações dos órgãos públicos.

Na ótica de Silva (apud TERROU, 2006), a informação é um mecanismo de difusão, colocado à disposição do público em geral, na forma de notícias, ideias e opiniões. Tavares (2013) leciona que o direito de liberdade assegurado na Constituição deve ser harmonizado com outros direitos fundamentais, tais como imagem, segurança etc., sob pena de caracterizar obrigação de indenizar. Já para Nunes (2005), a informação, como direito fundamental, pode ser desmembrado em três espécies: o direito de informar, o direito de se informar e o direito de ser informado. 
O direito de informar está inerente à ideia de liberdade de pensamento, liberdade de expressão intelectual, artística, científica e de comunicação, a inviolabilidade à intimidade, a honra, a vida privada e a honra (NUNES, 2005).

Quanto ao direito de se informar, condiz com a prerrogativa de tomar conhecimento de informações de cunho pessoal, inclusive resguardado por meio do remédio constitucional do Habeas Data. Já o direito de ser informado surge do dever de alguém de prestar informações (NUNES, 2005). Assim, qualquer pessoa pode solicitar informações pessoais, coletivas ou gerais aos órgãos estatais.

$\mathrm{O}$ direito à informação também tem o seu lugar na esfera do ordenamento infraconstitucional, em especial no CDC, por ser uma norma com raiz constitucional e objeto deste trabalho.

Ressalta-se que, devido à grande importância da informação para o equilíbrio das relações de consumo, em vários momentos a Lei Consumerista faz menção a ela. Pode-se visualizar a informação quando o Código fala dos princípios da Política Nacional das Relações de Consumo, dos Direitos Básicos do Consumidor, da Oferta etc.

De fato, a informação clara e ostensiva tem o condão de harmonizar as relações entre consumidor e fornecedor, pois muitas vezes, ao contratar, esse não tem a real dimensão das características da contratação, seja devido à omissão por parte do fornecedor ou, simplesmente, pelo fato de o consumidor, apesar de ter acesso à informação, não entender sua real dimensão.

Não são raras as vezes que, por mera deslealdade, o fornecedor omite ou apenas dificulta o acesso do consumidor à informação, podendo ser citado, a título de exemplo, as famosas letras miúdas ao final do contrato ou colocadas em nota de rodapé. Em outros casos, a informação é colocada à disposição do consumidor, mas, por não ter o conhecimento técnico ou jurídico necessário, não compreende a mensagem.

A carência de informação, não importando as razões que levaram a isso, deve ser sanada com políticas públicas sérias envolvendo tanto o Poder Público como o setor produtivo, pois cabe a ambos defender o consumidor, no sentido de educar as pessoas para consumir.

Ademais, não se pode utilizar do argumento de falta de informação ou a deficiência de análise da informação feita pelo consumidor para tolher mais ainda os meios de defesa de que ele dispõe. Não podemos olvidar que da mesma forma que é dever do Estado promover a defesa do Consumidor, também é papel do setor econômico utilizar meios para o equilíbrio das relações consumeristas. 


\section{O DIREITO DE INFORMAÇÃO COMO MECANISMO DE ATENUAÇÃO DOS RISCOS ATINENTES ÀS RELAÇÕES DE CONSUMO}

Partido da ideia de vulnerabilidade do consumidor no mercado, vez que esse não tem conhecimento do controle produtivo, o legislador trouxe a previsão expressa de que os produtos e serviços colocados no mercado de consumo não devem oferecer qualquer risco à saúde e à segurança do consumidor ${ }^{2}$.

Entretanto a legislação faz a ressalva para aqueles riscos decorrentes da natureza do produto ou do serviço a ser comercializado, devendo, nesse caso, o fornecedor informar ao consumidor de forma clara e precisa.

Nesse primeiro ponto, o legislador referiu-se aos riscos normais e previsíveis decorrentes da natureza do produto. Uma faca, potencialmente, traz risco à integridade física do consumidor, entretanto esse risco decorre da sua característica normal. Qualquer pessoa é capaz de identificar a nocividade intrínseca decorrente do instrumento de cozinha.

Nunes (2005) explica que, aqui, o legislador quis refere-se aos riscos decorrentes da normalidade e previsibilidade do uso rotineiro do produto ou serviço. Ao pensar ser possível que algum consumidor desconheça a potencialidade nociva do produto, entretanto, a norma buscou alcançar um grau de conhecimento padrão do consumidor.

Visualizada uma potencialidade nociva ao consumidor decorrente de uma característica própria do produto ou serviço, o legislador tentou equilibrar a relação de consumidor obrigando o fornecedor a prestar informações previamente. Tal decisão se justifica sob o argumento que, uma vez ciente dos riscos, o próprio consumidor tem a possibilidade de decidir sobre o seu uso ou não.

Dessa forma, a informação, direito constitucionalmente assegurado, se mostra como ferramenta de combate favorável ao consumidor, pois a partir do conhecimento dos riscos, ele se coloca em pé de igualdade com o fornecedor. Fato semelhante ocorre com os produtos modificados geneticamente, entendidos como aqueles que tiveram seu DNA alterado por meio do uso de tecnologia genética.

\footnotetext{
2 Art. $8^{\circ}$ Os produtos e serviços colocados no mercado de consumo não acarretarão riscos à saúde ou segurança dos consumidores, exceto os considerados normais e previsíveis em decorrência de sua natureza e fruição, obrigando-se os fornecedores, em qualquer hipótese, a dar as informações necessárias e adequadas a seu respeito. Parágrafo único. Em se tratando de produto industrial, ao fabricante cabe prestar as informações a que se refere este artigo, através de impressos apropriados que devam acompanhar o produto.
} 
É sabido que o emprego dessas tecnologias no setor agrícola permitiu que alguns víveres pudessem alcançar excelentes níveis de produtividade, possibilitando, assim, a produção de alimentos em escala industrial.

A necessidade do emprego de novas técnicas agrícolas se deu em razão do grande aumento da população global experimentado nas últimas décadas. Segundo dados na Organização das Nações Unidas (ONU), a população mundial em 2015 chegou a 7.3 milhões (online).

Muito embora existam fortes argumentos para o emprego de tecnologia que modifica a genética de determinados alimentos, sobretudo quanto à produtividade, ainda não se tem o conhecimento real se isso implica riscos aos consumidores. Os alimentos transgênicos já são uma prática realizada na agricultura mundial há algumas décadas, mas, apesar disso, não se sabe a verdadeira reação do corpo humano exposto a esse tipo de alimento durante um prolongado período de tempo.

Novamente aqui, diante desse cenário, a informação se apresenta como instrumento eficaz de prevenção.

\section{O PROJETO DE LEI N. 4.148/2008: AVANÇO OU RETROCESSO NA PRESTAÇÃO DA INFORMAÇÃO CONSUMIDOR DE ALIMENTOS GENETICAMENTE MODIFICADOS}

Tramita na Câmara dos Deputados o Projeto de Lei n. 4.148/2008, de autoria do Deputado Federal Luis Carlos Heinze (PP-RS), que visa a modificar as normas que regulamentam a rotulagem de alimentos geneticamente modificados.

Atualmente a normatização envolvendo a comercialização de produtos transgênicos está prevista na Lei n. 11.105, de 24 de março de 2005, na qual consta, em seu artigo 40, que os alimentos ingredientes alimentares destinados ao consumo humano ou animal que contenham ou que sejam produzidos a partir de transgênico ou derivados deverão conter informação nesse sentido em seus rótulos ${ }^{3}$.

\footnotetext{
${ }^{3}$ Art. 40. Os alimentos e ingredientes alimentares destinados ao consumo humano ou animal que contenham ou sejam produzidos a partir de OGM ou derivados deverão conter informação nesse sentido em seus rótulos, conforme regulamento.
} 
Apesar de ser anterior à aludida lei, a função de regulamentar o art. 40 da Lei de Biossegurança ficou a cargo do Decreto n. 4.680, de 24 de abril de 2003, dispondo que, na comercialização de alimentos e ingredientes geneticamente modificados, deve-se utilizar um símbolo definido pelo Ministério da Justiça, que editou a Portaria n. 2.658, de 22 de dezembro de $2013^{4}$.

Desde então, os alimentos ou ingredientes que contenham componentes geneticamente modificados devem ostentar na sua embalagem o símbolo contendo a letra "T" nas dimensões e formas definidas na referida portaria.

Pelo teor do projeto que altera as normas envolvendo a rotulagem dos alimentos com organismos geneticamente modificados, a obrigatoriedade de informar ao consumidor somente ocorreria quando o produto possuir mais de $1 \%$ na composição final, quando fossem realizados testes específicos ${ }^{5}$.

$\mathrm{O}$ autor do projeto sustenta a necessidade do seu projeto para que o Brasil adote padrões de normatização semelhantes aos existentes em outros países.

\footnotetext{
${ }^{4}$ Art. $2^{\mathrm{Q}} \mathrm{Na}$ comercialização de alimentos e ingredientes alimentares destinados ao consumo humano ou animal que contenham ou sejam produzidos a partir de organismos geneticamente modificados, com presença acima do limite de um por cento do produto, o consumidor deverá ser informado da natureza transgênica desse produto.

$\S 1^{\mathrm{O}}$ - Tanto nos produtos embalados como nos vendidos a granel ou in natura, o rótulo da embalagem ou do recipiente em que estão contidos deverá constar, em destaque, no painel principal e em conjunto com o símbolo a ser definido mediante ato do Ministério da Justiça, uma das seguintes expressões, dependendo do caso: "(nome

do produto) transgênico", "contém (nome do ingrediente ou ingredientes) transgênico(s)" ou "produto produzido a partir de (nome do produto) transgênico".

$\S 2^{\mathrm{O}}-\mathrm{O}$ consumidor deverá ser informado sobre a espécie doadora do gene no local reservado para a identificação dos ingredientes.

$\S 3^{\mathrm{O}-}$ A informação determinada no $\S 1^{\mathrm{O}}$ deste artigo também deverá constar do documento fiscal, de modo que essa informação acompanhe o produto ou ingrediente em todas as etapas da cadeia produtiva.

$\S 4^{0}-\mathrm{O}$ percentual referido no caput poderá ser reduzido por decisão da Comissão Técnica Nacional de Biossegurança - CTNBio.

5 Art. 40. Os rótulos dos alimentos destinados ao consumo humano, oferecidos em embalagem de consumo final, que contenham organismos geneticamente modificados, com presença superior a $1 \%$ de sua composição final, detectada em análise especifica, deverão informar o consumidor, a natureza transgênica do alimento.

$\S 1^{\circ}$. A informação estabelecida neste artigo deve constar nos rótulos dos alimentos embalados na ausência do consumidor, bem como nos recipientes de alimentos vendidos à granel ou in natura diretamente ao consumidor,

devendo ser grafada, em destaque, de forma legível, utilizando-se uma das seguintes expressões, dependendo do

caso: "(nome do produto) transgênico" ou "contém (nome do ingrediente) transgênico".

$\S 2^{\circ}$. Aos alimentos que não contenham organismos geneticamente modificados será facultada a rotulagem "livre de transgênicos", desde que tenham similares transgênicos no mercado brasileiro e comprovada a total ausência no alimento de organismos geneticamente modificados, através de análise específica.

$\S 3^{\circ}$. O direito à informação para os alimentos que envolvam organismos geneticamente modificados está disciplinado exclusivamente neste artigo e a sua não observância implicará na aplicação das penalidades previstas no Código de Defesa do Consumidor e demais normas aplicáveis.
} 
$\mathrm{Na}$ sua justificativa, consta que o modelo de rotulagem adotado atualmente não atende a necessidade de informar o consumidor, pois o induz a erro, seja pelo falso entendimento ou de conteúdo inútil, não informa ou "desinforma", já que não cumpre o papel de esclarecer, mas sim o de confundir ou de nada agregar. O Deputado acrescenta que a normatização brasileira envolvendo biotecnologia é extremamente politizada, e a rotulagem atualmente tem funcionado como uma contra propaganda, pois os signos utilizados não têm conteúdo esclarecedor.

Em síntese, os argumentos apresentados pelo Deputado Federal Luis Carlos Heinze partem da premissa de que o modelo utilizado não alcança sua finalidade, pois o destinatário final não compreende o significado dos símbolos indicativos nas embalagens dos produtos.

Diante da possibilidade da modificação das regras atuais, entidades públicas e privadas se manifestaram contrárias ao Projeto n. 4.148/2008, argumentando se tratar de um retrocesso na efetivação dos direitos do consumidor.

O Instituto de Defesa do Consumidor - IDEC passou a veicular uma campanha, em seus meios de divulgação institucional, denominada "Fim da Rotulagem dos alimentos transgênicos: diga não" (online). Outras entidades ligadas a movimentos sociais, segurança nutricional, meio ambiente também se manifestaram contrárias ao projeto.

$\mathrm{O}$ argumento utilizado por essas entidades consiste na insegurança dos consumidores decorrente da ausência de informação quanto à origem dos produtos disponibilizados no mercado de consumo, pois com a ausência da obrigatoriedade de se rotular alimentos transgênicos essa informação não mais seria repassada ao consumidor.

Salienta-se que, segundo o projeto, a rotulagem somente seria obrigatória em caso de realização de testes específicos, entretanto a lei não especifica as circunstâncias da realização desse teste específico. Segundo o IDEC, a detecção do DNA de produtos geneticamente modificados, uma vez sendo processado para a produção de alguns alimentos, não é viável (online).

No que pese a constatação científica da inviabilidade da detecção do DNA da por meio de testes científicos após a matéria prima ser processada para ser transformada em produtos como biscoito, margarina etc., ao se analisar o referido projeto de lei sob a ótica da constituição, conclui-se pela sua inviabilidade normativa.

Dentro da perspectiva de um ordenamento jurídico caracterizado pela supremacia da Constituição sobre as demais normas jurídicas, toda lei ou projeto de lei deve obediência ao texto constitucional. 
Na dicção de Silva (2006), a Constituição é a lei fundamental do Estado brasileiro, toda a autoridade, governo ou lei somente nela encontra fundamento. Os entes federativos têm o seu poder limitado expressa ou implicitamente pela Carta Magna.

Dentro dessa perspectiva, todas as normas legais ou infralegais que integram o ordenamento jurídico nacional somente serão válidas se estiverem em conformidade com a sistemática constitucional (SILVA, 2006).

Como dito alhures, o texto constitucional assegura o direito à informação, direito este também tratado de modo pormenorizado na seara infraconstitucional pelo Código de Defesa do Consumidor.

O direito à informação não é apenas uma mera solenidade ou meramente um dispositivo sem conteúdo normativo, sua pretensão vai além disso, pois permite uma compreensão da realidade por parte do consumidor. Salienta-se que, quando se trata de matéria de ordem constitucional, não se podem excluir direitos já reconhecidos pelo Estado.

No Estado Democrático de Direito, existe a proibição ao retrocesso dos direitos fundamentais como imperativo para assegurar a segurança e a estabilidade do ordenamento jurídico constitucional, exatamente para que se contraponha ao Estado Liberal (CONTO, 2006).

Sarlet (2005) leciona que a ideia de segurança jurídica está relacionada com as aspirações do ser humano, pois dela decorre a estabilidade das relações jurídicas e da própria ordem jurídica.

Diante da possibilidade do legislador, seja por meio de uma emenda à Constituição ou por meio de um projeto de lei que vise a suprimir determinada norma infraconstitucional que regulamente norma constitucional, depara-se com a noção de vedação ao retrocesso (SARLET, 2005).

Em síntese, uma das finalidades do Constituição preconizada pelo Estado Democrático de Direito é a imposição de um rol de direitos e garantias fundamentais, que tem como fito proteger o indivíduo do poder do Estado ou dos outros indivíduos. Assim, em razão da característica histórica dos direitos fundamentais, pode o Estado reconhecer, a qualquer tempo, novos direitos fundamentais, entretanto, uma vez reconhecidos esses direitos, não mais pode o Estado retroceder.

Essa conclusão pode ser extraída do texto constitucional quando, nos limites do poder de reformar a constituição, veda-se a emenda à Constituição tendente a abolir direitos 
fundamentais ${ }^{6}$.

Percebe-se que os direitos fundamentais não são imutáveis na sua essência, é possível existir uma emenda constitucional versando sobre o tema, desde que não implique retrocesso.

O caso ora analisado se amolda, em princípio, ao lecionado por Sarlet, pois a constituição prevê expressamente o direito de o indivíduo ter acesso à informação. E esse direito na esfera legal ganha status de direito básico do consumidor, sendo assegurada a prerrogativa de o consumidor ser informado de forma clara e ostensiva sobre todas as características alusivas à relação de consumo, sobretudo no tocante à composição e aos riscos decorrentes do produto ${ }^{7}$.

${ }^{6}$ Art. 60. A Constituição poderá ser emendada mediante proposta:

I - de um terço, no mínimo, dos membros da Câmara dos Deputados ou do Senado Federal;

II - do Presidente da República;

III - de mais da metade das Assembleias Legislativas das unidades da Federação, manifestando-se, cada uma delas, pela maioria relativa de seus membros.

$\S 1^{\circ}$ A Constituição não poderá ser emendada na vigência de intervenção federal, de estado de defesa ou de estado de sítio.

$\S 2^{\circ}$ A proposta será discutida e votada em cada Casa do Congresso Nacional, em dois turnos, considerando-se aprovada se obtiver, em ambos, três quintos dos votos dos respectivos membros.

$\S 3^{\circ} \mathrm{A}$ emenda à Constituição será promulgada pelas Mesas da Câmara dos Deputados e do Senado Federal, com o respectivo número de ordem.

$\S 4^{\circ}$ Não será objeto de deliberação a proposta de emenda tendente a abolir:

I - a forma federativa de Estado;

II - o voto direto, secreto, universal e periódico;

III - a separação dos Poderes;

IV - os direitos e garantias individuais.

$\S 5^{\circ}$ A matéria constante de proposta de emenda rejeitada ou havida por prejudicada não pode ser objeto de nova proposta na mesma sessão legislativa.

${ }^{7}$ Art. $6^{\circ}$ São direitos básicos do consumidor:[...]

III - a informação adequada e clara sobre os diferentes produtos e serviços, com especificação correta de quantidade, características, composição, qualidade, tributos incidentes e preço, bem como sobre os riscos que apresentem; 
Ademais, o argumento apresentado pelo autor do projeto é falacioso, pois afirma que, se o direito não é efetivo, deve ser suprimido. De fato, muitos consumidores que se utilizam de produtos no mercado não entendem a real dimensão dos símbolos utilizados para identificar produtos criados a partir de matéria prima modificada geneticamente, porém não se deve tolhê-los desse direito por não ser ele efetivo. Ademais, retroceder na efetivação de direitos fundamentais fragiliza as relações jurídicas e o ordenamento jurídico, o que viola, consequentemente, o Estado Democrático de Direito.

É razoável que o destinatário final, principal interessado, conheça os riscos efetivos ou potenciais dos produtos e serviços que está consumindo. Assim, o Projeto de Lei n. 4.148/2008 se revela inconstitucional por violar flagrantemente o direito dos consumidores de serem informados sobre as características do que estão comprando no supermercado e levando para sua família consumir.

\section{CONSIDERAÇÕES FINAIS}

É sabido que a Constituição da República Federativa do Brasil traz a informação como direito fundamental, inclusive disponibilizando um remédio constitucional para restabelecer esse direito em caso de sua violação.

A premissa do direito à informação permite que o consumidor supere a dificuldade de julgamento diante da possibilidade de ele usufruir de um produto ou serviço colocado a sua disposição. Trata-se de direito fundamental, com fito de proteger a autonomia do cidadão consumidor, frente às possíveis escolhas. A garantia de tal de direito é de suma importância por meio da preservação da autonomia da vontade.

No tocante ao uso de novas tecnologias no processo de produção de produtos e na prestação de serviço, a informação é utilizada como contrapeso para reequilibrar a relação jurídica se contrapondo com a sociedade de risco. Frise-se que não basta apenas informação por informação. A mesma deve ser clara e compreensível. Caso contrário, não há como garantir-se a autonomia das decisões das pessoas, pois a escolha consciente demanda real conhecimento sobre o objeto.

No caso em tela - acesso à devida informação sobre a procedência dos organismos que compõem determinados alimentos, sejam transgênicos ou não - é inadmissível cogitar a possibilidade de se tolher direitos (autonomia da vontade e devido conhecimento) das pessoas, 
devidamente assegurados pela Constituição Federal, sob pena de retrocessos principiológico e normativo, o que pode acarretar sérios problemas jurídicos no âmbito prático.

O presente trabalho buscou analisar a compatibilidade do Projeto de Lei 4.148/2208 frente aos princípios constitucionais fundamentados no Estado Democrático de Direito. Tal análise também fora realizada frente ao Decreto n. 4.080/2003 e ao Código de Defesa do consumidor. Constatou-se da inconsistência da essência de tal projeto, considerando a vulnerabilidade do cidadão frente aos interesses das transnacionais e do mercado econômico. Some-se a isso a necessidade da devida precaução frente às incertezas dos avanços biotecnológicos.

Não se pretende, com este estudo, ataque gratuito ao avanço científico. Propõe-se, isso sim, devida cautela frente a uma temática que ainda traz incertezas quanto às possíveis consequências para com a saúde humana. Logo, é de suma importância a devida preservação da autonomia da vontade do cidadão, bem como garantir facilidade e transparência quanto às informações sobre alimentos que possuam em sua composição organismos geneticamente modificados.

Assim, o Projeto de Lei n. 4.148/2008 consiste em um retrocesso no sistema de efetivação aos direitos constitucionais, no tocante à concretização do direito à informação, pois retira do consumidor um direito já conquistado. Dessa forma, é dever do Estado (de direito) buscar, por meio da edição de normas e da execução de políticas públicas, devida efetividade a essa premissa constitucional.

\section{REFERÊNCIAS}

AFONSO, Luis Fernando. Precaução e consumo. A aplicação do princípio da precaução nas relações de consumo. 2011. Disponível em:

<http://www.egov.ufsc.br/portal/conteudo/precau\%C3\%A7\%C3\%A3o-e-consumoaplica\%C3\% A7\% $3 \%$ A3o-do-princ\%C3\% ADpio-da-precau\%C3\% A7\%C3\%A3o-nasrela\%C3\% A7\%C3\%B5es-de-consumo>. Acesso em 5 set. 2015.

Beck U. Sociedade de risco: rumo a uma outra modernidade. Tradução de Sebastião Nascimento. São Paulo: Ed. 34; 2010.

BENJAMIN, Antônio Herman V.; MARQUES, Cláudia Lima; BESSA, Leonardo Roscoe. Manual de direito do consumidor. São Paulo: RT, 2007.

BITTAR, Carlos Alberto. Direitos do consumidor. 5. ed. Rio de Janeiro: Forense Universitária, 2002. 
BRASIL. Câmara dos Deputados. Projeto de Lei Ordinária PL 4.148/2008. Altera e acresce dispositivos à Lei n. 11.105, de 24 de março de 2005. Disponível em:

<http://www.camara.gov.br/proposicoesWeb/fichadetramitacao?idProposicao=412728>.

Acesso em: 5 set. 2015.

Conselho da Justiça Federal. Enunciado n. 27 da I Jornada de Direito Civil do

Conselho da Justiça Federal. Disponível em:

<http://daleth.cjf.jus.br/revista/enunciados/IJornada.pdf>. Acesso em: 5 set. 2015.

. Constituição (1988). Constituição da República Federativa do Brasil. Brasília, DF: Senado, 1988.

Decreto n. 4.680, de 24 de abril de 2003. Regulamenta o direito à informação, assegurado pela Lei no 8.078, de 11 de setembro de 1990, quanto aos alimentos e ingredientes alimentares destinados ao consumo humano ou animal que contenham ou sejam produzidos a partir de organismos geneticamente modificados, sem prejuízo do cumprimento das demais normas aplicáveis. Disponível em:

<http://www.planalto.gov.br/ccivil_03/decreto/2003/d4680.htm>. Acesso em: 5 set. 2015.

. Lei n. 10.406 de 10 de janeiro de 2002. Institui o Código Civil. Disponível em: <http://www.planalto.gov.br/ccivil_03/leis/2002/110406.htm〉. Acesso em: 5 set. 2015.

Lei n. 11.105, de 24 de março de 2005. Regulamenta os incisos II, IV e V do § 1o do art. 225 da Constituição Federal, estabelece normas de segurança e mecanismos de fiscalização de atividades que envolvam organismos geneticamente modificados - OGM e seus derivados, cria o Conselho Nacional de Biossegurança - CNBS, reestrutura a Comissão Técnica Nacional de Biossegurança - CTNBio, dispõe sobre a Política Nacional de Biossegurança - PNB, revoga a Lei no 8.974, de 5 de janeiro de 1995, e a Medida Provisória no 2.191-9, de 23 de agosto de 2001, e os arts. 5o, 6o, 7o, 8o, 9o, 10 e 16 da Lei no 10.814, de 15 de dezembro de 2003, e dá outras providências. Disponível em:

<http://www.planalto.gov.br/ccivil_03/_ato2004-2006/2005/lei/111105.htm>. Acesso em: 5 set. 2015.

Lei n. 8.078, de 11 de setembro de 1990. Dispõe sobre a proteção do consumidor e dá outras providências. Disponível em: <http://www.planalto.gov.br/ccivil_03/leis/L8078.htm>. Acesso em: 5 set. 2015.

Portaria n. 2.658, de 22 de dezembro de 2013. Definir o símbolo de que trata o art.

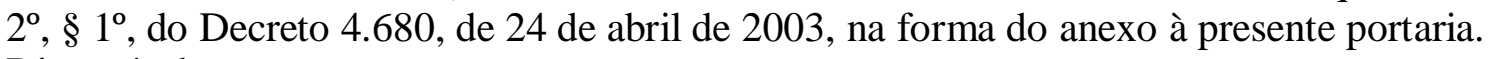
Disponível em:

<http://portal.anvisa.gov.br/wps/wcm/connect/1e3d43804ac0319e9644bfa337abae9d/Portaria _2685_de_22_de_dezembro_de_2003.pdf?MOD=AJPERES>. Acesso em: 5 set. 2015.

. Supremo Tribunal Federal. REsp 1009591 RS 2007/0278724-8. Disponível em: <http://stj.jusbrasil.com.br/jurisprudencia/16832676/recurso-especial-resp-1009591-rs-20070278724-8/inteiro-teor-16832677>. Acesso em: 5 set. 2015.

CONTO, Mario de. O princípio da vedação ao retrocesso social: uma análise a partir dos pressupostos da hermenêutica filosófica. UNISSINOS. 2006. 149 f. dissertação (Mestrado em Direito) - Pós-graduação em Direito, Faculdade de Direito, Universidade do Vale do Rio Sinos, São Leopoldo, 2006. 
IDEC. Instituto Brasileiro de Defesa do Consumidor. Disponível em:

http://www.idec.org.br/mobilize-se/campanhas/fim-da-rotulagem-dos-alimentos-transgenicosdiga-no>. Acesso em: 5 set. 2015.

LOPEZ, Teresa Ancona. Responsabilidade civil na sociedade de risco. Revista da Faculdade de da Universidade de São Paulo. 2010. Disponível em:

<http://www.revistas.usp.br/rfdusp/article/viewFile/67932/70540>. Acesso em: 5 set. 2015.

NEVES, Daniel Amorim Assumpção; TARTUCE, Flávio. Manual de direito do consumidor. São Paulo: Método, 2012.

NUNES, Rizzatto. Comentários ao Código de Defesa do Consumidor. São Paulo: Saraiva, 2005 .

SARLET, Ingo Wolfgang. A eficácia do direito fundamental à segurança jurídica: dignidade da pessoa humana, direitos fundamentais e proibição de retrocesso social no direito constitucional brasileiro. Revista brasileira de direito público - RBDP. Belo Horizonte, ano 3, n. 11, out./dez. 2005.

SILVA, José Afonso. Curso de direito constitucional. 27.ed. São Paulo: Malheiros, 2006.

SIRVINSKAS, Luis Paulo. Manual de direito ambiental. 2. ed. São Paulo: Saraiva, 2003.

TAVARES, André Ramos. Curso de direito constitucional. São Paulo: Saraiva, 2013. 